\title{
CHANGES IN THE QUALITY AND NUTRIENT CONTENT OF SWEET PEPPER AND TOMATO AFTER PHOSPHITE FOLIAR FERTILIZER TREATMENTIN HYDROCULTUREIN DIFFERENT GROWING SEASONS
}

\author{
Zsuzsanna Tóthné Taskovics ${ }^{1 *}$, András Kovács ${ }^{1}$, Judit Petö ${ }^{2}$ and András Palkovics ${ }^{3}$ \\ ${ }^{1}$ Department of Horticulture, Faculty of Horticulture and Rural Development, John von Neumann University, \\ Hungary \\ ${ }^{2}$ Department of Agricultural Science, Faculty of Horticulture and Rural Development, John von Neumann \\ University, Hungary \\ ${ }^{3}$ Department of Rural Development, Faculty of Horticulture and Rural Development, John von Neumann \\ University, Hungary \\ https://doi.org/10.47833/2020.2.AGR.036
}

\section{Keywords:}

tomato

sweet pepper

nutrient content

vitamin C

phosphitefoliar fertilizer

\section{Article history: \\ Received 15 May 2020 \\ Revised 20 May 2020 \\ Accepted 25 May 2020}

\begin{abstract}
The primary goal of economical vegetable production is to achieve a satisfactory yield. Nowadays, however, the production of high-quality products with a high quality and healthy food components is becoming an equally important aspect.Achieving high vitamin and mineral element content in vegetables belong to these expectations. In our present research we studied the effect of a phosphite containing foliar fertilizer in three different doses on the dry matter and vitamin $C$ content of forced sweet pepper and tomato, in two different growing seasons.
\end{abstract}

\section{Introduction}

The goal of vegetable production nowadays is not only the increase of the yield, but to grow healthy foods. Environmentally conscious plant nutrition contributes to this goal greatly. The aim of farmers is to grow plants in environmentally friendly circumstances and the lowering of chemicals use.

Demand for functional foods is increasing so farmers are forced to produce vegetables having beneficial effects on health conditions of the consumers, rather when these foods are consumed regularly Sweet pepper is an expert source of vitamin $C$ and other vitamins, carotenoids, minerals and carbohydrates [3,11]. Vitamin $C$ is a strong antioxidant molecule and immune system strengthening agent. It supports the effect of other antioxidants such as vitamin $E$ and carotenoids [14]. The consumption of sweet pepper and tomato is possible in whole the year nowadays, as in addition to field cultivation, they can also be efficiently grown in forced hydro culture. Sweet pepper and tomato may be expert source of minerals and antioxidants in whole year in this way, serve as functional foods and may be the base of healthy nourishmentThey have low energy content, low fat, and high water soluble dietary fiber contents $[1,4,5,7,9]$.

Light and illumination intensity directly affects the quantity of vitamin $\mathrm{C}$. The higher the light intensity during the production, the higher the vitamin $\mathrm{C}$ content of the plant tissues, but too high temperature affects the vitamin content negatively $[8,10]$. In our present study we compare two vegetable

In the last few years summer months were characterized with extreme weather, high daytime temperature and ultraviolet radiation. Plants react to sudden changes in temperaturewith stress.

\footnotetext{
* Corresponding author. Tel.: +36 76517631

E-mail address: tothne.zsuzsanna@kvk.uni-neumann.hu
} 
Stress adversely affects nutrient transport in the plant, ultimately resulting worse quality and quantity of the yield[6].

Our previous research showed that the application of phosphite containing fertilizers increase the vitamin $C$ content of sweet peppers in open field trials $[12,13]$. In our present investigations we were on the following of this relation in forced hydro cultural sweet pepper. We wanted to examine the effect of foliar fertilizer in the case of tomato test plants as well. Our study was made in spring and autumn as well. As one of the most important indicators of the nutritional value of sweet pepper and tomato is the vitamin $\mathrm{C}$ content., possible increase in this antioxidant vitamin should contribute to the role of these plants as functional foods

\section{Method}

The trial was set up in a small airspace polytunnelof the Faulty of Horticulture and Rural Development, John von Neumann University. Seedlings were planted in two different seasons, in spring and autumn, so being able to assess 2 growing periods in a year. Spring growing has started on $13^{\text {th }}$ of March 2019, while the autumn production has started on $13^{\text {th }}$ of August 2019. Seedlings were planted in coconut fiber medium.

In one treatment, 12 plants were tested in the case of sweet pepper, and 6 plants in the case of tomato. Each treatment was made in four repetitions. Sweet pepper cultivar had white flesh with a conical fruit shape. Tomato type involved in our experiment was an ever-growing bunch of tomatoes.

In addition to normal nutrient solution, in some treatments, a phosphite containing product Smaragd extra (Agroqinter S.L.) was applied, in different manner, for six weeks. This product is a foliar fertilizer, but in our investigation,stems were irrigated with it, in a $0.1 \mathrm{~L} / \mathrm{stem}$ manner occasionally.

Treatments were the following:

Control - untreated, normal nutrient solution.

$1^{\text {st }}$ treatment: Smaragd extra three occasions/week

$2^{\text {nd }}$ treatment: Smaragd extra twice a week

$3^{\text {rd }}$ treatment: Smaragd extra once a week.

Fruit samples have been taken at harvest time in both production periods. In the spring growing season samples were taken twice, on $20^{\text {th }}$ of June and $23^{\text {rd }}$ of July, In autumn fruit samples were taken on $7^{\text {th }}$ of November.

Dry matter and the main nutrient contents were measured by certified methods in the Soil and Plant Testing Laboratory of our Faculty. Fresh fruit samples were thoroughly homogenized in rotary blended grinder. Dry matter content was measured in air-dried samples gravimetrically. For nutrient studies, powdered samples were digested in a microwave device by means of concentrated nitric acid and hydrogen peroxide $\left(210^{\circ} \mathrm{C}, 20\right.$ minutes, Milestone Ethos Plus). Macro element contents were measured by ICPatomic emission spectrometer (ICP-AES, Horiba) using standard methods. Nitrogen (organic and ammonium nitrogen) concentration was tested by Kjeldahl method after sulphuric acid digestion (FOSS Kjeltec).

Vitamin C levels were determined in 1:10 water extracts of grinded fresh fruit. Vitamin C was determined by redox titrimetry [2].

\section{Results}

Laboratory samples have been analyzed for dry matter, nutrient and vitamin $\mathrm{C}$ content. Dry matter in the samples did notdiffer between the first sampling in spring and autumn in the case of sweet pepper (Figure 1.). 


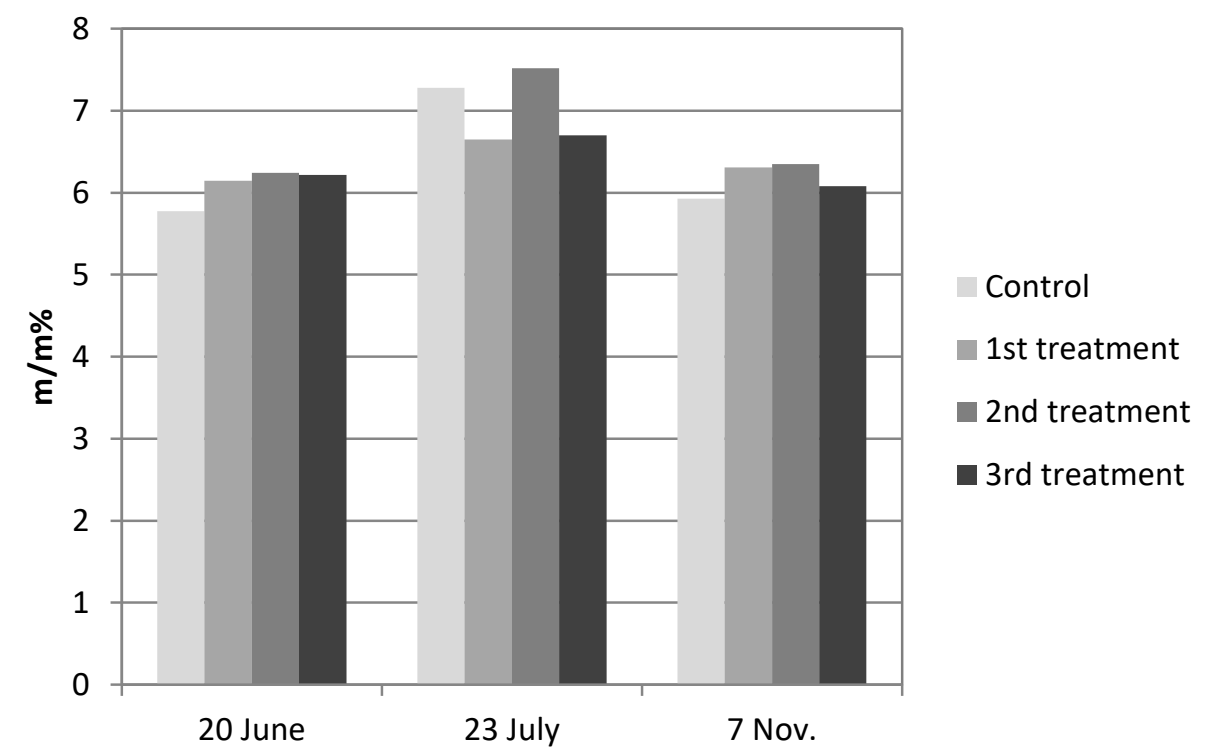

Figure 1. Dry matter of sweet pepper fruits in spring and autumn harvest time ( $\mathrm{m} / \mathrm{m} \%)$.

After phosphite treatments we got higher levels in both harvests, compared to the control, but the differences were not significant. Samples collected in July showed higher levels, however, Treatment resulted lower levels than that measured in the control plants.

Regarding results of tomato experiment, we showed higher dry matter contents in July, but differences were slight after treatments, compared to control (Figure 2.)

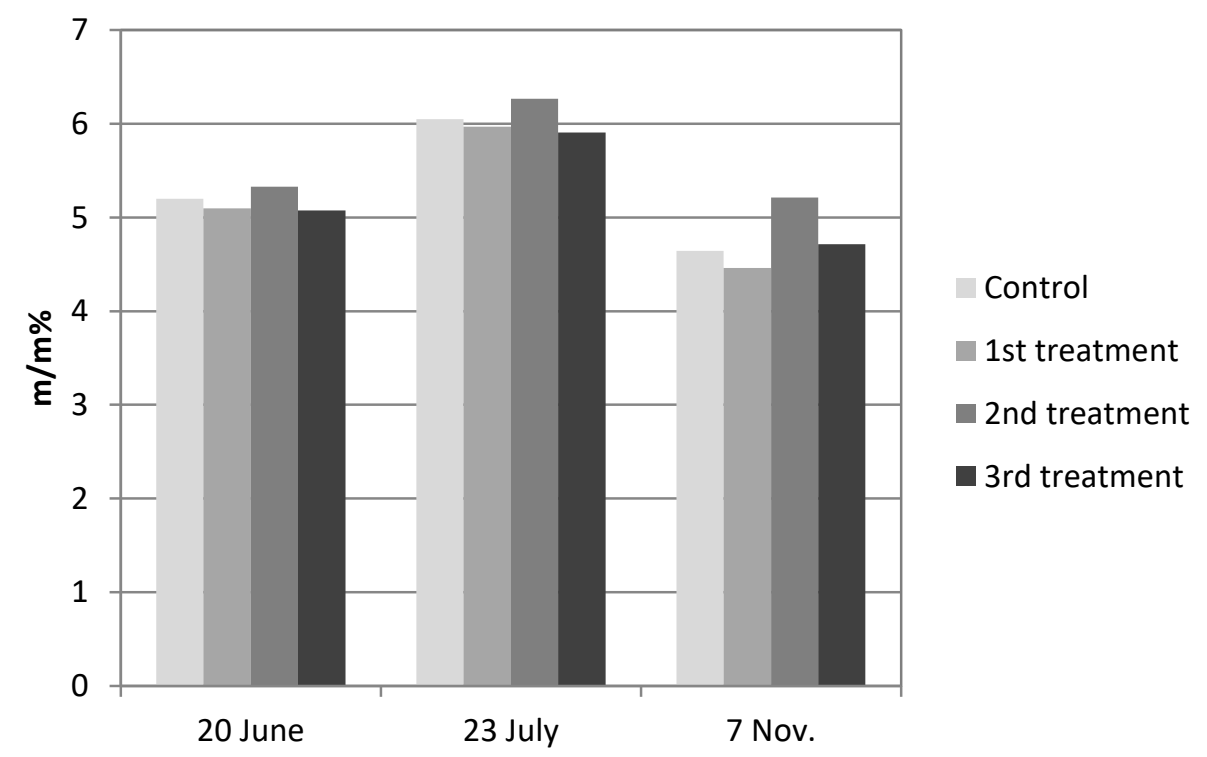

Figure 2. Dry matter of tomato fruits in spring and autumn harvest time $(\mathrm{m} / \mathrm{m} \%)$.

Vitamin $\mathrm{C}$ contents showed much more varied results. In peppers takenat the first spring sampling, the values were in $25-35 \mathrm{mg} / 100 \mathrm{~g}$ range, but the values of the samples taken from the treated plants were all lower than the values of the control plants. However, in the samples examined at the next two time points, the effect of the treatments revealed, as all the treatments resulted higher amount of vitamin $\mathrm{C}$ in the pepper berries compared to the control (Figure 3). The effect of treatments and period were more visible in the results measured in tomatoes (Figure 4). In all samples, higher values were measured in the berries taken from the treated plants compared to 
the berries of the control plants. Values between 25 and $35 \mathrm{mg}$ were measured for the first sample, as for peppers, but 40-55 mg/100 g was obtained for the second sampling, which was not the case for peppers. For autumn sampling, values ranged from 15 to $18 \mathrm{mg} / 100 \mathrm{~g}$. This supports the state of the scientificliterature that the vitamin $\mathrm{C}$ content of berries decreases as the light intensity decreases. We found a significant difference between the results ofTreatment 1 and 2 . in tomato.

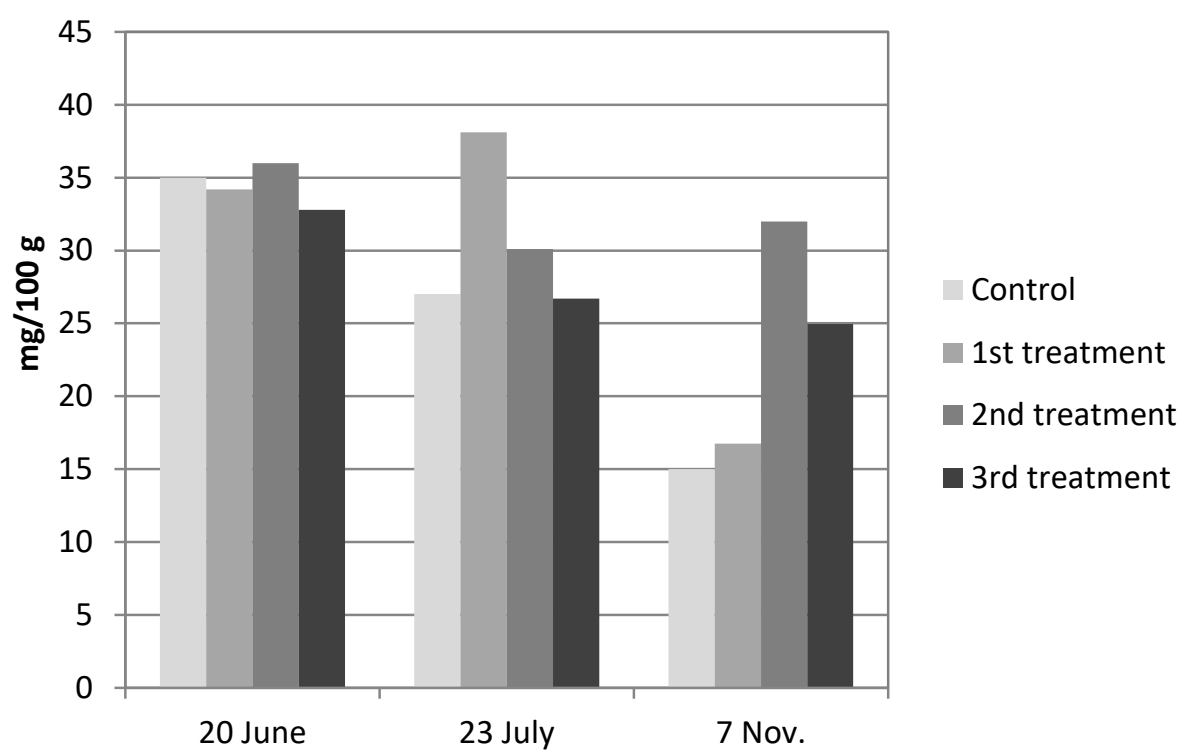

Figure 3. Vitamin C content of sweet pepper fruits in spring and autumn harvest time $(\mathrm{mg} / 100 \mathrm{~g})$

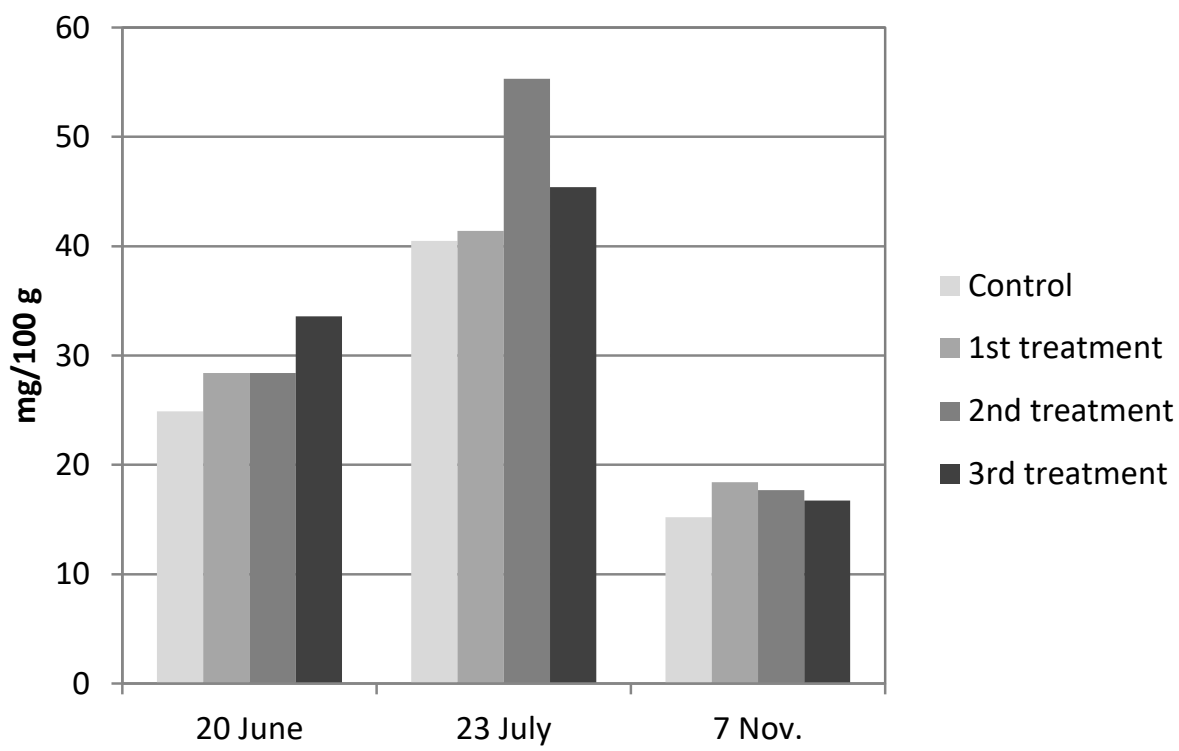

Figure 4. Vitamin C content of tomato fruits in spring and autumn harvest time ( $\mathrm{mg} / 100 \mathrm{~g})$

In the case of the main nutrients in the berry - nitrogen, phosphorous, potassium, calcium and magnesium - we observed no significant differences between periods and treatments. 


\section{Discussion, conclusion}

The effects of the different foliar fertilizers on the main nutrient contents of sweet pepper and tomato fruits were not supported by statistical evidence.

$\mathrm{C}$ vitamin contents were higher in sweet pepper fruits after different phosphite treatments in July and November.

Some observed differences werelikely to be caused by environmental factors, e.g. high temperature and fluctuating temperaturein spring, whereas low light intensity in autumn. These circumstances could contribute to the changes in nutrient contents. The reliability of our results have been greatly impacted by the fact that the polytunnel had little airspace, the temperature was very high, while the relative humidity was low during the production, especially in the spring season.

\section{Acknowledgment}

Thank for the support of the research carried out in the framework of the EFOP-3.6.2-162017-00012 „Developing a functional, healthy and safe food product chain model from field to table in a thematic research network". The project is funded by the Hungarian State and the European Union, co-financed by the European Social Fund, and is part of the Széchenyi 2020 program.

\section{References}

[1] Aldrich, H. T., Salandanan, K., Kendall, P., Bunning, M., Stonaker, F., Külen, O., \& Stushnoff, C. (2010). Cultivar choice provides options for local production of organic and conventionally produced tomatoes with higher quality and antioxidant content. Journal of the Science of Food and Agriculture, 90(15), 2548-2555., DOI: $10.1002 /$ jsfa.4116

[2] Bné, Pető, J., Kovács, A., Tóthné, Taskovics, Zs. (2004) Hajtatott paradicsomfajták beltartalmi értékeinek vizsgálata, Magyar Tudomány Ünnepe kiadvány, Kecskemét, 5:23-28

[3] Deepa, N., Kaur, C., Singh, B., \& Kapoor, H. C. (2006). Antioxidant activity in some red sweet pepper cultivars. Journal of Food Composition and Analysis, 19(6-7), 572-578. DOI: 10.1016/j.jfca.2005.03.005

[4] Gahler S, Otto K, Bohm V (2003). Alterations of vitamin C, total phenolics, and antioxidant capacity as affected by processing tomatoes to different products. J. Agric. Food Chem. 51: 7962-7968.

[5] Gonzalez-Cebrino, F., Lozano, M., Ayuso, M. C., Bernalte, M. J., Vidal-Aragon, M. C., \& Gonzalez-Gomez, D. (2011). Characterization of traditional tomato varieties grown in organic conditions. Spanish Journal of Agricultural Research, 9(2), 444-452.

[6] Horinka T., Knipf R. (2007) Zöldségnövények hiánybetegségei és klimatikus hatások tünetei. Kertészek kis/Nagy Áruháza, Mórahalom. ISBN: 978-963-06-1861-8.

[7] Kapoulas N, llić ZS, Đurovka M, Trajković R, Milenković L (2011). Effect of organic and conventional production practices on nutritional value and antioxidant activity of tomatoes. Afr. J. Biotechnol 10(71): 15938-15945.

[8] Lee S. K., Kader A. A. (2000) Preharvest and postharvest factors influencing vitamin C content of horticultural crops. Postharvest Biology and Technology 20:207-220. DOI: 10.1016/S0925-5214(00)00133-2

[9] Lichthammer A. (2007) A paprika (Capsicum annuum) táplálkozásélettani vonatkozásai és helye az egészséges táplálkozásban. 5

[10] Richardson A. C., Marsh K. B., Boldingh H. L., Pickering A. H., Bulley S. M., Frearson N. J., Ferguson A. R., Thornber S. E., Bolitho K. M., Macrae E. A. (2004) High growing temperature reduce fruit carbohydrate and vitamin C in kiwifruit. Plant Cell Environ 27:423-435. DOI: 10.1111/j.1365-3040.2003.01161.x

[11] Terbe I., Hodossi S., Kovács A.(2005) Zöldségtermesztés termesztőberendezésekben. Mezőgazda Kiadó, Budapest. ISBN: 978-963-286-204-0.

[12] Tóthné, TaskovicsZsuzsanna ;Kovács, András ; Mihálka, Virág ; Molnárné, Hoffmann Zita(2019): Foszfit tartalmú lombtrágyák hatása hajtatott paradicsom termésmennyiségére és minőségére In: Kőszegi, Irén Rita (szerk.) III. Gazdálkodás és Menedzsment Tudományos Konferencia :Versenyképesség és innováció

Kecskemét, Magyarország : Neumann JánosEgyetem, pp. 1164-1168. , 5 p.

[13] Tóthné, Taskovics Zsuzsanna ;Kovács, András ; Mihálka, Virág ; Molnárné, Hoffmann Zita. (2019): Hajtatott paprika termésmennyiségének és minőségének alakulása foszfit tartalmú lombtrágyázás hatására GRADUS $6: 2$ pp. 59-63. , 5 p

[14] Varga Z., Gilingerné Pankotai M. (2008) Zöldségfélék bioaktív anyagainak hatása a emberi egészségre. Agrárunió 9:57-59. 